\begin{tabular}{cc|c}
\hline Tar. Bil. Der. & Tarım Bilimleri Dergisi & Journal of Agricultural Sciences \\
& $\begin{array}{c}\text { Dergi web sayfası: } \\
\text { www.agri.ankara.edu.tr/dergi }\end{array}$ & Journal homepage: \\
& www.agri.ankara.edu.tr/journal
\end{tabular}

\title{
Green Long Pepper Growth under Different Saline and Water Regime Conditions and Usability of Water Consumption in Plant Salt Tolerance
}

\author{
Ali ÜNLÜKARA ${ }^{\mathrm{a}}$, Ahmet KURUNÇ ${ }^{\mathrm{b}}$, Bilal CEMEK ${ }^{\mathrm{c}}$ \\ ${ }^{a}$ Erciyes University, Faculty of Agriculture Seyrani, Department of Biosystem Engineering, Kayseri, TURKEY \\ ${ }^{\boldsymbol{b}}$ Akdeniz University, Faculty of Agriculture, Department of Farm Structures and Irrigation, Antalya, TURKEY \\ ${ }^{c}$ Ondokuzmayls University, Faculty of Agriculture, Department of Farm Structures and Irrigation, Samsun, TURKEY
}

\section{ARTICLE INFO}

Research Article DOI: 10.1501/Tarimbil_0000001318

Corresponding Author: Ali ÜNLÜKARA, E-mail: unlukara@gmail.com, Tel: +90 (506) 2915299

Received: 27 November 2013, Received in Revised Form: 24 March 2014, Accepted: 16 June 2014

\begin{abstract}
Both electrical conductivity of soil saturation paste extract $\left(\mathrm{EC}_{\mathrm{e}}\right)$ and plant water consumption $(\mathrm{ET})$ should be considered for assessing crop yield tolerances to salinity since ET decreases by increased salinity effects. In this study, conducted in a greenhouse under controlled conditions, it was afforded to use soil salinity and water consumption for the purpose of assessing plant responses to salinity. Additionally, growth and yield of green long pepper (Capsicum annuum L. Demre) under different saline and water regime conditions were examined. For these purposes, the green long pepper were exposed to six water salinity levels $\left(\mathrm{S}_{1}=0.65 ; \mathrm{S}_{2}=2.0 ; \mathrm{S}_{3}=3.0 ; \mathrm{S}_{4}=4.0 ; \mathrm{S}_{5}=5.0\right.$ and $\left.\mathrm{S}_{6}=7.0 \mathrm{dS} \mathrm{m}^{-1}\right)$ and four water application rates $\left(\mathrm{IR}_{1}=1.43 ; \mathrm{IR}_{2}=1.0 ; \mathrm{IR}_{3}=0.75\right.$ and $\mathrm{IR}_{4}=0.50$ times of depleted water $)$. The yield response factor $\left(\mathrm{K}_{\mathrm{y}}\right)$, is 1.56 for salinity stress and 1.66 for water stress. Water consumption of the plant exponentially decreased $(\mathrm{ET}=$ $0.83 \times \mathrm{EC}_{\mathrm{e}}^{-0.17}$ ) whereas relative fruit yield decreased linearly $(7.03 \%)$ for unit increase in soil salinity after a threshold value of $1.20 \mathrm{dS} \mathrm{m}^{-1}$. A stronger three-dimensional relation was found among relative yield, relative water consumption and soil salinity $\left(\mathrm{R}^{2}=0.94\right)$. Using water consumption as a second factor in evaluation of plant response to salinity may be useful for reflecting effects of different climatic conditions.
\end{abstract}

Keywords: Capsicum annuum L. Demre; Water consumption; Salinity; Water deficiency; Yield response factor; Salinity model

\section{Farklı Tuzluluk ve Sulama Rejimi Şartlarında Sivri Biber Gelişimi ve Bitki Tuzluluk Toleransında Su Tüketiminin Kullanılabilirliği}

\section{ESER BILGISII}

Araştırma Makalesi

Sorumlu Yazar: Ali ÜNLÜKARA, E-posta:unlukara@gmail.com, Tel: +90 (506) 2915299 Geliş Tarihi: 27 Kasım 2013, Düzeltmelerin Gelişi: 24 Mart 2014, Kabul: 16 Haziran 2014

\section{ÖZET}

Bitki su tüketiminin artan tuzluluğun etkisiyle azalmasından dolayı, bitkilerin tuzluluğa karşı toleranslarının belirlenmesinde, toprağın saturasyon çamuru ekstraktı elektriksel iletkenliği $\left(\mathrm{EC}_{\mathrm{e}}\right)$ ile bitki su tüketimi (ET) birlikte 
değerlendirilmelidir. Kontrollü şartlarda serada yürütülen bu çalışmada bitkilerin tuzluluğa karşı tepkilerinin değerlendirilmesinde toprak tuzluluğu ve bitki su tüketimi birlikte dikkate alınmıştır. Buna ilaveten sivri biberin (Capsicum annuum L. Demre) farklı tuz ve su rejimi şartları altında verim ve gelişmesi incelenmiştir. Bu amaçla, sivri biber altı düzeyde sulama suyu tuzluluğuna $\left(\mathrm{S}_{1}=0.65 ; \mathrm{S}_{2}=2.0 ; \mathrm{S}_{3}=3.0 ; \mathrm{S}_{4}=4.0 ; \mathrm{S}_{5}=5.0\right.$ ve $\left.\mathrm{S}_{6}=7.0 \mathrm{dS} \mathrm{m} \mathrm{m}^{-1}\right)$ ve dört su uygulama oranına (tüketilen suyun $\mathrm{IR}_{1}=1.43 ; \mathrm{IR}_{2}=1.0 ; \mathrm{IR}_{3}=0.75$ ve $\mathrm{IR}_{4}=0.50$ katı) maruz birakılmıştır. Tuzluluk stresi için verim tepki faktörü $\left(\mathrm{K}_{\mathrm{y}}\right) 1.56$ ve su stresi için 1.66 olarak belirlenmiştir. Birim toprak tuzluluğu artışı için $1.20 \mathrm{dS} \mathrm{m}^{-1}$ eşik değerinden sonra nispi meyve verimi doğrusal şekilde azalırken (\% 7.03), su tüketimi üstel şekilde azalmıştır (ET= $\left.0.83 \times \mathrm{EC}_{\mathrm{e}}^{-0.17}\right)$. Nispi verim, nispi su tüketimi ve toprak tuzluluğu arasında çok kuvvetli üç boyutlu ilişki bulunmuştur $\left(\mathrm{R}^{2}=0.94\right)$. Bitkilerin tuzluluğa karşı streslerinin belirlenmesinde ikinci bir faktör olarak su tüketiminin kullanılması, farklı iklim şartlarının etkisinin yansıtılmasında yararlı olabilecektir.

Anahtar Kelimeler: Capsicum annuum L. Demre; Su tüketimi; Tuzluluk; Su kısıtı; Verim tepki faktörü; Tuzluluk modeli

(C) Ankara Üniversitesi Ziraat Fakültesi

\section{Introduction}

Pepper is cultivated nearly all over the world and 29601 Mt produced from 1837704 ha area in 2011. Turkey is the third of largest pepper producer (1975 Mt) after China (15520 Mt) and Mexico (2131 Mt) (FAOSTAT $2014 \mathrm{a}, \mathrm{b}$ ).

In general, irrigated agriculture has faced the challenge of sustaining its productivity for centuries. As well as irrigation-induced activities, soil and water salinity and sodicity problems continue to plague agricultural production. In order to produce sufficient food for the world's growing population, control of these problems, increasing productivity of water use in agriculture and also finding new ways to utilize the extensive sodic and saline soils and water resources are vital and urgent. In this respect, proper utilization of water for both plant growth and soil salinity control is important and necessary (Pessarakli \& Szabolcs 1999).

Maas \& Hoffman (1977) developed a salt tolerance model and the model widely accepted by the other researchers studied on salinity. According to the model, plants tolerate or stand soil salinity until a threshold value and then linear yield reduction was seen for unit increase in soil salinity. Air temperature, humidity and air pollution influence plant salt tolerance significantly. In general, most crops are more tolerance to salinity under cool, humid conditions than under hot, dry conditions (Hoffman \& Letey 1990). For the same plant, salt tolerances may also change between varieties of that plant. In Maas \& Hoffman model (1977) climate effects were not considered on plant salt tolerance.

Plant water consumption also decreased with increasing soil salinity. Letey \& Dinar (1986) stated that different conditions for evapotranspiration were obtained by applying different soil moisture regimes but rarely by using saline water. Ozturk et al (2004) reported decreasing effect of salinity on water consumption for lemon balm, Yurtseven et al (2005) for tomato, Ünlükara et al (2008) for okra, Düzdemir et al (2009) for cowpea, Ünlükara et al (2010) for eggplant, Kurunc et al (2011) for bell pepper. Plant water consumption also changes with changing climatic conditions. In hot and dry climate, plants deplete more water than in warm and humid climate. Water consumption increases with increasing solar radiation, temperature and wind speed and decrease with increasing relative humidity. In other words, water consumption is a combined result of weather conditions for a given plant.

The first objective of this study is to determine the water consumption changes under saline conditions and effort to use the water consumption as a second factor with soil salinity for assessment of plant salinity responses in case of long green pepper. The second objective is to determine the relation between relative yield decrease and evapotranspiration decrease under water stress and salinity stress. Final purpose is to determine the effects of salinity and water stress on long pepper yield, fruit number and quality, vegetative and root growth. 


\section{Material and Methods}

To determine the plant water consumption, growth, yield and yield quality of long green pepper (Capsicum annuиm l. Demre) under different saline and water regime conditions, two experiments were conducted under greenhouse conditions in Tokat province of Turkey. In the experiment 1, plants were exposed to six different irrigation water salinity levels $\left(\mathrm{S}_{1}=0.65 ; \mathrm{S}_{2}=2.0 ; \mathrm{S}_{3}=3.0 ; \mathrm{S}_{4}=4.0\right.$; $\mathrm{S}_{5}=5.0$ and $\mathrm{S}_{6}=7.0 \mathrm{dS} \mathrm{m}^{-1}$ ) and in the experiment 2, plant were exposed to four different amount of irrigation water $\left(\mathrm{IR}_{1}=1.43 ; \mathrm{IR}_{2}=1.0 ; \mathrm{IR}_{3}=0.75\right.$ and $\mathrm{IR}_{4}=0.50$ times of depleted water from the field capacity) after seedling establishment. $\mathrm{S}_{1}$ and $\mathrm{IR}_{2}$ treatments were control treatments of the first and second experiments, respectively. Both experiments were conducted in a randomized block design with 5 replications between 10 June and 20 September in 2006 .

To determine water depletion precisely, the pepper were grown in weighing pots like lysimeters. Therefore, water depletion was monitored by weighing the pots and irrigation water amounts were calculated by using Equation (1) for the treatments of salinity and Equation (2) for the treatments of irrigation regimes experiments (Ozturk et al 2004; Yurtseven et al 2005; Ünlükara et al 2008; Kurunc et al 2011):

$$
\begin{gathered}
I W=\frac{\frac{\left(W_{P F C}-W_{P}\right)}{\rho_{w}}}{1-L F} \\
I W=\frac{\left(W_{P F C}-W_{P}\right)}{\rho_{w}} \times C_{I R}
\end{gathered}
$$

Where; IW is the amount of irrigation water application (L); LF is the leaching fraction (taken as $\mathrm{LF}=0.30) ; \mathrm{W}_{\mathrm{PFC}}$ is the pot weight $(\mathrm{kg})$ at field capacity; $\mathrm{W}_{\mathrm{P}}$ is the pot weight ( $\mathrm{kg}$ ) just before irrigation; $r_{w}$ is the unit mass of water $\left(1 \mathrm{~kg} \mathrm{~L}^{-1}\right)$ and $\mathrm{C}_{\mathrm{IR}}$ is the water application coefficient for irrigation regime experiment.
After each irrigation application, collected drainage water in a drain pan under each pot observed until drainage water flows from pot orifices nearly ceased and then measured. Irrigation applications were performed between 3 and 6 day intervals throughout the experiment before readily available water in control treatments was not depleted. Water balance method was used to calculate the evapotranspiration (ET) between two consecutive irrigations (Unlukara et al 2008; Yurtseven et al 2005).

In order to eliminate the effects of sodium adsorption ratios (SAR), saline waters were prepared by using the calculated amounts of $\mathrm{CaCl}_{2}$, $\mathrm{MgSO}_{4}$ and $\mathrm{NaCl}$ considering the desired salinity levels for the treatments of salinity experiment. Prepared saline waters for each treatment were stored in 100 liter-plastic containers. $\mathrm{EC}_{\mathrm{i}}$ of these waters were controlled by an EC/pH meter (Jenway 430 model) before each irrigation application and the adjustment was done if necessary (Ünlükara et al 2008; Düzdemir et al 2009; Ünlükara et al 2010). Tap water $\left(\mathrm{EC}_{\mathrm{i}}=0.65 \mathrm{dS} \mathrm{m} \mathrm{m}^{-1}\right)$ was used to irrigate of the control treatment in the salinity experiment and the treatments of the irrigation regime experiment.

Sandy loam textured soil with $17 \%$ clay, $16.2 \%$ silt and $66.8 \%$ sand and a unit weight of $1.57 \mathrm{~g} \mathrm{~cm}^{-3}$ was used in both experiments. The gravimetric soil water hold at saturation and field capacity were $26.1 \%$ and $15.8 \%$, respectively. Forty-five $\mathrm{kg}$ of airdried soil was used to fill each pot with $33 \mathrm{~cm}$ height, $32 \mathrm{~cm}$ bottom and $39 \mathrm{~cm}$ top diameters and 32.7 $\mathrm{dm}^{3}$ in volume. Amount of fertilizer to be applied to each pot were calculated by considering $135 \mathrm{~kg}$ $\mathrm{ha}^{-1}$ for $\mathrm{N}, 37.5 \mathrm{~kg} \mathrm{ha}^{-1}$ for $\mathrm{P}$ and $75 \mathrm{~kg} \mathrm{ha}^{-1}$ for $\mathrm{K}$ as suggested by Doorenbos \& Kassam (1986). All of the $\mathrm{P}$ as diammonium phosphates (DAP) and $\mathrm{K}$ as potassium sulphate $\left(\mathrm{K}_{2} \mathrm{SO}_{4}\right)$ and one half of the $\mathrm{N}$ were applied to each treatment before transplanting whereas other half of the $\mathrm{N}$ applied after 20 days from initiation of the experiments. Some part of $\mathrm{N}$ requirement were derived from DAP and the rest from ammonium nitrate fertilizers. 
Green pepper seedlings were transplanted to the lysimeters in 10 June 2006 and the plants were exposed to saline waters or different amounts of irrigation waters after one week from ones transplanted. As ripened, fruits were harvested throughout the experiments until September 20 (Totally 103 days from the transplanting to the last harvest).

At each harvest, the harvested fruits were weighted as fresh and oven-dried at $70{ }^{\circ} \mathrm{C}$ to a constant dry weight in order to determine fruit dry matter ratio. A reflectometer was used to determine the total soluble solids (TSS) as brix. At the end of the experiment, plant heights and stem diameters were measured, the plants were cut at $1 \mathrm{~cm}$ above the soil surface and vegetative fresh and dry weights (oven-dried at $70{ }^{\circ} \mathrm{C}$ to a constant weight) were obtained for each replication. Just after the plants were cut, soil samples were taken from entire depth of root zone of each pot to determine electrical conductivities of the saturated soil paste extracts $\left(\mathrm{EC}_{\mathrm{e}}\right)$ by an $\mathrm{EC} / \mathrm{pH}$ meter (Jenway 430 model) (Richards 1969). After soil sampling, the plant roots were gently removed from each pot by washing the soil inside the pot to determine plant root lengths, fresh and dry weights.

Salt tolerance model suggested by Maas \& Hoffman (1977) was used in order to evaluate plant response to salinity. The yield response factors $\left(\mathrm{K}_{\mathrm{y}}\right)$ for both water and salinity stresses were obtained (Stewart \& Hagan 1973; Doorenbos \& Kassam 1986).

To evaluate the effects of salinity on long pepper, three dimensional regression analyses were carried out. Three dimensional models of long green pepper that relates relative yield $\left(\mathrm{Y}_{\mathrm{a}} / \mathrm{Y}_{\mathrm{m}}\right)$ against to soil salinity $\left(\mathrm{EC}_{\mathrm{e}}\right)$ and relative evapotranspiration $\left(\mathrm{ET}_{\mathrm{a}} /\right.$ $\mathrm{ET}_{\mathrm{m}}$ ) were obtained. The experimental data were analyzed using SPSS statistical analysis software (SPSS Inc. USA 2002). The General Linear Model procedure was used to perform analysis of variance. Duncan's multiple range test was used to separate means of the data at 0.05 level of significance.

\section{Results and Discussion}

\subsection{Effect of irrigation water salinity on soil salinity}

Electrical conductivity of soil saturation paste extracts $\left(\mathrm{EC}_{\mathrm{e}}\right)$ for each treatment was presented in Table 1 for the salinity and in Table 2 for the irrigation regime experiment. As expected, soil salinities increased with increasing electrical conductivities of irrigation water $\left(\mathrm{EC}_{\mathrm{i}}\right)$. Electrical conductivity of soil saturation paste extracts $\left(\mathrm{EC}_{\mathrm{e}}\right)$ of $\mathrm{S}_{1}, \mathrm{~S}_{2}, \mathrm{~S}_{3}, \mathrm{~S}_{4}, \mathrm{~S}_{5}$ and $\mathrm{S}_{6}$ treatments increased by $1.0,1.4,1.7,1.8,2.1$ and 1.9 times, respectively with respect to their irrigation water salinity levels. Leaching fraction (LF), among the treatments was not statically significant (Table 1) and LF values were around 0.30 for salinity experiment. In irrigation regime experiment, the highest $\mathrm{EC}_{\mathrm{e}}(2.04$ $\mathrm{dS} \mathrm{m}^{-1}$ ) was obtained for $\mathrm{IR}_{2}$ treatment to which complete crop requirement was applied, and the lowest $\mathrm{EC}_{\mathrm{e}}\left(0.64 \mathrm{dS} \mathrm{m}^{-1}\right)$ was for $\mathrm{IR}_{1}$ treatment to which excess irrigation water was applied (Table 2). The $\mathrm{EC}_{\mathrm{e}}$ value of $\mathrm{IR}_{1}$ treatment was not significantly different from that of the $\mathrm{IR}_{4}$ treatment. $\mathrm{EC}_{\mathrm{e}}$ of $\mathrm{IR}_{2}$, $\mathrm{IR}_{3}$ and $\mathrm{IR}_{4}$ increased by 3.1, 1.5 and 1.4 times, respectively with respect to tap water electrical conductivity $\left(0.65 \mathrm{dS} \mathrm{m}^{-1}\right)$.

\subsection{Effects of salinity and amount of irrigation water on fruit yield}

For both experiments, yield differences among the treatments were statically significant at 0.01 probability level (Tables 1 - 2).

For the salinity experiment, the highest fruit yield (471.5 g) was obtained from $\mathrm{S}_{1}$ and the lowest fruit yield from $\mathrm{S}_{6}(103.2 \mathrm{~g})$ and $\mathrm{S}_{5}(168.0 \mathrm{~g})$ treatments. The relative fruit yield decrease against salinity was plotted in Figure 1 and a slope decrease of $7.03 \%$ was determined after the threshold value of $1.20 \mathrm{dS} \mathrm{m}{ }^{-1}$. Hoffman \& Letey (1990) reported that pepper (Capsicum annuum) was a moderately sensitive vegetable with a $1.5 \mathrm{dS} \mathrm{m}^{-1}$ threshold value and a $14.0 \%$ yield decrease slope while Rhoades et al (1992) also reported that pepper is a moderately sensitive vegetable but with a $1.7 \mathrm{dS} \mathrm{m}^{-1}$ threshold 
Table 1- Impact of irrigation water salinity on soil salinity and some plant variables of pepper (Capsicum annuum)

Çizelge 1- Sulama suyu tuzluluğunun toprak tuzluluğuna ve biberin bazı özelliklerine etkisi (Capsicum annuum)

\begin{tabular}{lcccccccc}
\hline \multirow{2}{*}{ Analysis } & \multicolumn{7}{c}{ Treatments $\left(d S m^{-1}\right)$} \\
\cline { 2 - 8 } & $S_{1}(0.65)$ & $S_{2}(2.0)$ & $S_{3}(3.0)$ & $S_{4}(4.0)$ & $S_{5}(5.0)$ & $S_{6}(7.0)$ & Mean & $P>F$ \\
\hline EC $_{\mathrm{e}}\left(\mathrm{dS} \mathrm{m}^{-1}\right)$ & $0.64 \mathrm{~d}$ & $2.77 \mathrm{~d}$ & $5.22 \mathrm{c}$ & $7.29 \mathrm{c}$ & $10.45 \mathrm{~b}$ & $13.48 \mathrm{a}$ & 6.51 & $*$ \\
LF & 0.28 & 0.28 & 0.28 & 0.31 & 0.29 & 0.30 & 0.29 & $\mathrm{NS}$ \\
Yield $\left(\right.$ g pot $\left.^{-1}\right)$ & $471.5 \mathrm{a}$ & $326.3 \mathrm{~b}$ & $309.1 \mathrm{~b}$ & $198.5 \mathrm{c}$ & $168.0 \mathrm{~cd}$ & $103.2 \mathrm{~d}$ & 266.0 & $*$ \\
Number of fruit & $33.6 \mathrm{a}$ & $25.6 \mathrm{~b}$ & $26.0 \mathrm{~b}$ & $20.4 \mathrm{bc}$ & $17.5 \mathrm{c}$ & $14.4 \mathrm{c}$ & 23.1 & $*$ \\
Fruit dry mat. $(\%)$ & $6.83 \mathrm{~d}$ & $8.25 \mathrm{c}$ & $9.23 \mathrm{bc}$ & $9.45 \mathrm{~b}$ & $10.93 \mathrm{a}$ & $11.36 \mathrm{a}$ & 9.29 & $*$ \\
TSS (Brix) & $5.04 \mathrm{~d}$ & $6.16 \mathrm{c}$ & $6.42 \mathrm{bc}$ & $6.99 \mathrm{ab}$ & $6.78 \mathrm{bc}$ & $7.66 \mathrm{a}$ & 6.50 & $*$ \\
Stem dia. $(\mathrm{mm})$ & $10.6 \mathrm{a}$ & $10.4 \mathrm{a}$ & $10.4 \mathrm{a}$ & $9.2 \mathrm{~b}$ & $9.1 \mathrm{~b}$ & $8.2 \mathrm{c}$ & 9.6 & $*$ \\
Plant height $(\mathrm{cm})$ & $66.8 \mathrm{a}$ & $59.8 \mathrm{ab}$ & $66.0 \mathrm{a}$ & $51.2 \mathrm{~b}$ & $51.5 \mathrm{~b}$ & $38.0 \mathrm{c}$ & 55.7 & $*$ \\
Veg. dry wght $(\mathrm{g})$ & $24.7 \mathrm{a}$ & $20.4 \mathrm{a}$ & $21.1 \mathrm{a}$ & $14.1 \mathrm{~b}$ & $13.6 \mathrm{~b}$ & $8.2 \mathrm{c}$ & 17.1 & $*$ \\
Root length $(\mathrm{cm})$ & $35.4 \mathrm{abc}$ & $38.4 \mathrm{ab}$ & $39.8 \mathrm{a}$ & $33.0 \mathrm{bc}$ & $35.0 \mathrm{abc}$ & $31.4 \mathrm{c}$ & 35.5 & $* *$ \\
Root dry wght $(\mathrm{g})$ & $5.11 \mathrm{a}$ & $4.33 \mathrm{a}$ & $4.50 \mathrm{a}$ & $3.06 \mathrm{~b}$ & $2.92 \mathrm{~b}$ & $1.95 \mathrm{c}$ & 3.67 & $*$ \\
ET (liter) & $77.5 \mathrm{a}$ & $61.3 \mathrm{~b}$ & $60.5 \mathrm{~b}$ & $52.0 \mathrm{c}$ & $48.7 \mathrm{~cd}$ & $43.0 \mathrm{~d}$ & 57.5 & $*$ \\
WUE (g kg-1) & $6.10 \mathrm{a}$ & $5.32 \mathrm{a}$ & $5.07 \mathrm{a}$ & $3.79 \mathrm{~b}$ & $3.46 \mathrm{bc}$ & $2.39 \mathrm{c}$ & 4.39 & $*$ \\
\hline
\end{tabular}

\#, each value is the mean of five replications; ${ }^{t}$, within rows, means followed by the same letter are not significantly different according to Duncan's multiple range test at 0.05 significance level; *, **, significant at the 0.01 and 0.05 probability levels respectively; NS, non-significant; TSS, total soluble solids (Brix); WUE, water use efficiency (fresh yield (g)/water consumption $(\mathrm{kg})$

Table 2- Impact of irrigation water amount on soil salinity and some plant variables of pepper (Capsicum annuum)

Çizelge 2- Sulama suyu miktarının toprak tuzluluğuna ve biberin bazı özelliklerine etkisi (Capsicum annuum)

\begin{tabular}{|c|c|c|c|c|c|c|}
\hline \multicolumn{7}{|c|}{ Treatments } \\
\hline & $I R_{1}(1.43)$ & $I R_{2}(1.00)$ & $I R_{3}(0.75)$ & $I R_{4}(0.50)$ & Mean & $P>F$ \\
\hline $\mathrm{EC}_{\mathrm{e}}\left(\mathrm{dS} \mathrm{m}^{-1}\right)$ & $0.64 \mathrm{c}$ & $2.04 a$ & $1.00 \mathrm{~b}$ & $0.88 b c$ & 1.14 & * \\
\hline Yield $\left(\mathrm{g} \mathrm{pot}^{-1}\right)$ & $471.5 \mathrm{ab}$ & $502.4 \mathrm{a}$ & $407.3 \mathrm{~b}$ & $229.0 \mathrm{c}$ & 402.6 & $*$ \\
\hline Number of fruit & $33.6 b$ & $37.0 \mathrm{a}$ & $31.2 \mathrm{~b}$ & $19.4 \mathrm{c}$ & 30.3 & $*$ \\
\hline Fruit dry mat. (\%) & $6.83 c$ & $7.87 \mathrm{~b}$ & $8.44 \mathrm{ab}$ & $8.98 \mathrm{a}$ & 8.03 & $*$ \\
\hline TSS (Brix) & $5.04 \mathrm{c}$ & $5.83 b$ & $6.28 \mathrm{ab}$ & $6.55 \mathrm{a}$ & 5.92 & $*$ \\
\hline Stem dia. $(\mathrm{mm})$ & $10.6 \mathrm{a}$ & $11.0 \mathrm{a}$ & $10.5 \mathrm{a}$ & $9.4 b$ & 10.4 & $*$ \\
\hline Plant height (cm) & 66.8 & 72.2 & 64.8 & 61.4 & 66.3 & NS \\
\hline Veg. dry wght (g) & $24.7 \mathrm{bc}$ & $31.3 \mathrm{a}$ & $27.9 \mathrm{ab}$ & $21.6 \mathrm{c}$ & 26.4 & $*$ \\
\hline Root length (cm) & 35.4 & 42.2 & 36.4 & 39.6 & 38.4 & NS \\
\hline Root dry wght (g) & $5.11 \mathrm{~b}$ & $6.69 \mathrm{a}$ & $5.98 \mathrm{ab}$ & $5.21 b$ & 5.75 & $*$ \\
\hline ET (liter) & $77.5 \mathrm{a}$ & $66.0 \mathrm{~b}$ & $58.0 \mathrm{c}$ & $45.3 \mathrm{~d}$ & 61.7 & $*$ \\
\hline WUE ( $\left.\mathrm{g} \mathrm{kg}^{-1}\right)$ & $6.10 \mathrm{~b}$ & 7.61a & $7.01 \mathrm{ab}$ & $5.07 \mathrm{c}$ & 6.45 & $*$ \\
\hline
\end{tabular}

\#, each value is the mean of five replications; ${ }^{t}$, within rows, means followed by the same letter are not significantly different according to Duncan's multiple range test at 0.05 significance level; *,**, significant at the 0.01 and 0.05 probability levels respectively; NS, non-significant; TSS, total soluble solids (Brix); WUE, water use efficiency (fresh yield (g)/water consumption $(\mathrm{kg})$ 
and a $12.0 \%$ yield decrease slope. Kurunç et al (2011) found that the threshold salinity was $1.2 \mathrm{dS}$ $\mathrm{m}^{-1}$ and slope was $10.9 \%$ for bell peppers grown in pots under greenhouse conditions. Chartzoulakis \& Klapaki (2000) found $1.8 \mathrm{dS} \mathrm{m}^{-1}$ threshold salinities for Sonar and Lamuyo hybrids of Capsicum annuum but they found yield decrease slopes $8.4 \%$ for Sonar and $11.7 \%$ for Lamuyo.

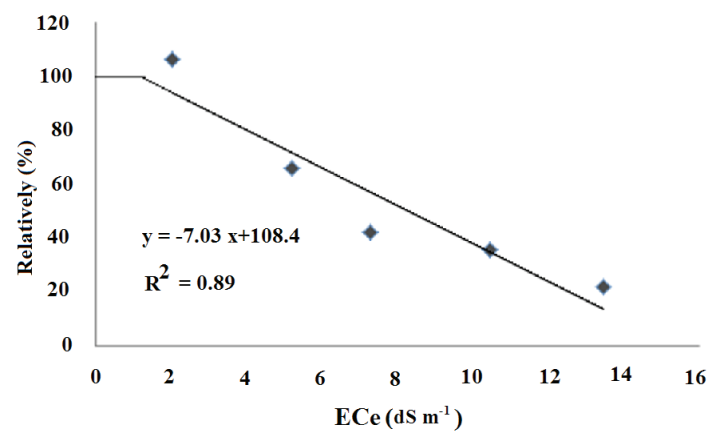

Figure 1- The relationship between soil salinity and green long pepper fruit yield

Şekil 1- Toprak tuzluluğu ve sivri biberin meyve verimi arasındaki ilişsi

For irrigation regime experiment, the highest fruit yields were obtained from $\operatorname{IR}_{2}(502.4 \mathrm{~g})$ and $\mathrm{IR}_{1}$ $(471.5 \mathrm{~g})$ treatments whereas the lowest yield (229 g) for $\mathrm{IR}_{4}$ treatment. Compared to $\mathrm{IR}_{2}$ treatment, yield decreases for $\mathrm{IR}_{3}$ and $\mathrm{IR}_{4}$ treatments were $18.9 \%$ and $54.4 \%$, respectively. Water stress caused yield lost because as soil become drier, soil water strongly held by soil matrix and the concentration of soil water increase. Dorji et al (2005) only applied half water of control treatment to treatments of partial root zone drying (PRD) and deficit irrigation (DI) and found $19 \%$ and $34.7 \%$ total fresh fruit yield lost in PRD and DI, respectively for hot pepper.

Effects of salinity and water deficit on fruit number and mean fruit weight were found significantly different. Number of fruit per plant and mean fruit weight were reduced by salinity (Table 1). Limited water applications caused decreases in harvested fruit number and mean fruit weight. Chartzoulakis \& Klapaki (2000) under saline conditions and Dorji et al (2005) under different water deficit strategies also found similar effects of these stresses.

Both salinity and water stress improve fruit dry matter ratio and total soluble solids (TSS) (Tables 1 - 2). Dry matter contents of treatments changed between $6.83 \%$ for $\mathrm{S}_{1}$ and $11.36 \%$ for $\mathrm{S}_{6}$. TSS 5.04 for $\mathrm{S}_{1}$ improved to 7.66 for $\mathrm{S}_{6}$. Relative yield reduction slope for dry fruit was $4.8 \%$ and it was lower than those of fresh fruit yield. Under water stressed conditions fruit dry matter increased from $6.83 \%$ for $\mathrm{IR}_{1}$ to $8.98 \%$ for $\mathrm{IR}_{4}$ and TSS from 5.04 brix for $\mathrm{IR}_{1}$ to 6.55 brix for $\mathrm{IR}_{4}$. Increment in dry matter ratio moderated dry fruit yield lost under both saline and water stress conditions, which agree with Dorji et al (2005) and Ezzo et al (2010).

Vegetative dry weight, plant height, stem diameter and root dry weight were significantly affected by salinity (Table 1). Non-significant differences among these characteristics were not observed until $5.22 \mathrm{dS} \mathrm{m}^{-1}$ of soil salinity $\left(\mathrm{S}_{3}\right)$. After this point, increasing soil salinity reduced vegetative, root dry weights, plant height and stem diameter, significantly. Aktas et al (2006), Chartzoulakis \& Klapaki (2000), Genhua et al (2010) and Azuma et al (2010) stated depressed pepper vegetative growth because of salinity. In the water regimes experiment, water stress did not affect plant height and root length statistically but decreased vegetative and root dry weights and stem diameter (Table 2).

\subsection{Water consumption}

Differences in water consumptions due to salinity and water stress were statistically significant at 0.01 probability level (Tables $1-2$ ). The highest water consumption (77.5 liter pot $\left.^{-1}\right)$ was observed for $\mathrm{S}_{1}$ treatment and the lowest for $\mathrm{S}_{6}$ (43.0 liter pot $\left.^{-1}\right)$ and $S_{5}\left(48.7\right.$ liter pot $\left.{ }^{-1}\right)$. The decreases in the water consumptions with respect to the control were $20.9 \%, 21.8 \%, 32.9 \%, 37.2 \%$ and $44.4 \%$ for $\mathrm{S}_{2}, \mathrm{~S}_{3}, \mathrm{~S}_{4}, \mathrm{~S}_{5}$ and $\mathrm{S}_{6}$ treatments respectively. In the irrigation regime experiment, evapotranspiration was reduced by application of limited water, thus the lower evapotranspiration amount were obtained for $\mathrm{IR}_{3}$ and $\mathrm{IR}_{4}$ treatments. The highest ET was determined for $\mathrm{IR}_{1}$. The ET decrease for $\mathrm{IR}_{2}, \mathrm{IR}_{3}$ 
and $\mathrm{IR}_{4}$ with respect to $\mathrm{IR}_{1}$ were $14.8 \%, 25.2 \%$ and $41.5 \%$, respectively.

Decreasing effect of salinity on plant evapotranspiration should be considered to prevent excess water application. The following equation, offered by Allen et al (1998), was used to adjust evapotranspiration under saline conditions:

$$
E T_{a d j}=K_{s} \times E T_{m}
$$

Where; $\mathrm{ET}_{\mathrm{a}}$ or $\mathrm{ET}_{\mathrm{adj}}$ is the actual or adjusted evapotranspiration under saline conditions; $\mathrm{ET}_{\mathrm{m}}$ is the maximum evapotranspiration of the control treatment (Liters); $\mathrm{K}_{\mathrm{s}}$ is the stress coefficient.

To determine stress coefficient $\left(\mathrm{K}_{\mathrm{s}}\right), \mathrm{ET}_{\mathrm{a}} / \mathrm{ET}_{\mathrm{m}}$ ratios for saline treatments were plotted against soil salinity values (Figure 2). The relationship between $\mathrm{ET}_{\mathrm{a}} / \mathrm{ET}_{\mathrm{m}}$ and $\mathrm{ECe}$ was curvilinear $\left(\mathrm{R}^{2}=0.93\right)$ :

$$
\frac{E T_{a}}{E T_{m}}=K_{s}=0.83(E C e)^{-0.17}
$$

Plant salt tolerance model developed by Hoffman $\&$ Maas (1977) have been used to quantify salinity effect on plant yield. In the model, relative yield percent is dependent variable whereas electrical conductivity of soil saturation extract (ECe) is independent variable. Plant tolerances may change with changing of climate, soil and management conditions and plant varieties. For example, a plant is able to tolerate some degree of salinity under cold climate but it is not able to tolerate the same salinity and lost considerable yield under hot climate. Plants consumed more water under hot climate then cold climate. Sunshine, temperature, wind velocity and relative humidity affect plant evapotranspiration. Because of these reasons, using water consumption in the salinity model may reflect the effect of climatic conditions. For this respect, relative evapotranspiration and soil salinity as independent variables and relative yield ratio as dependent variable were used to develop a three-dimensional model (Figure 3). Very stronger relation was found among these three variables $\left(\mathrm{R}^{2}=0.94\right)$ :

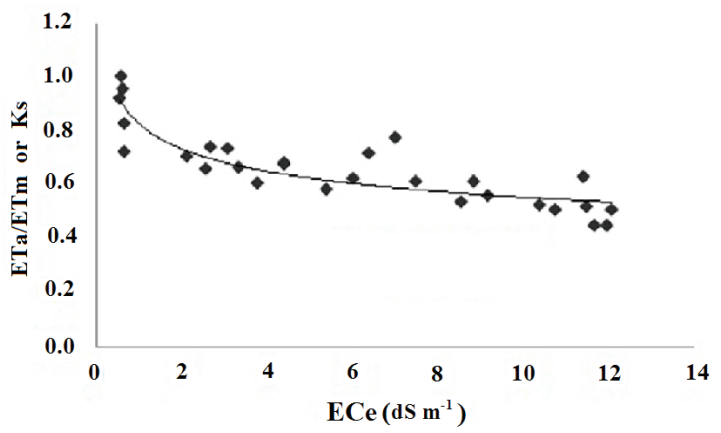

Figure 2- Effect of soil salinity on green long pepper evapotranspiration $\left(\mathrm{SE}=0.032 ; \mathrm{R}^{2}=0.73 ; \mathbf{P}<0.01\right)$

Şekil 2- Toprak tuzluluğunun sivri biberin bitki su tüketimine etkisi $\left(S E=0.032 ; R^{2}=0.73 ; P<0.01\right)$

Similar three-dimensional relationship among soil salinity, evapotranspiration and yield/plant growth data were offered by Cemek et al (2011) for lettuce. Different from Cemek et al (2011) model, we afforded to find relationship among relative yield, soil salinity and relative evapotranspiration. We think that by using relative evapotranspiration and relative yield in the model, the effect of different climatic conditions on salt tolerance for a given plant would be considered.

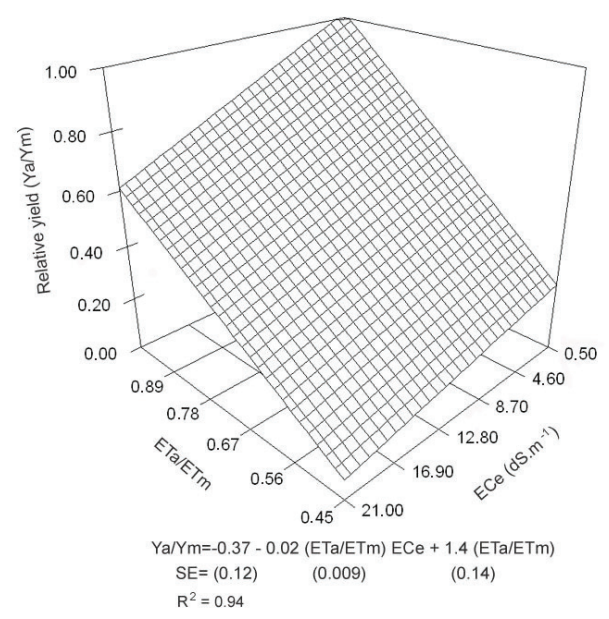

Figure 3- Three-dimensional relations among relative green long pepper yield, relative evapotranspiration and soil salinity

Şekil 3-Sivri biberin nisbi verimi, nisbi bitki su tüketimi ve toprak tuzluluğunun üç boyutlu ilişkisi 
In spite of depressed yield and water consumption under saline and water deficit conditions, there were significant differences in water use efficiency (WUE) among the treatments of the both experiments (Table 1-2). In the salinity experiment WUE decreased after $\mathrm{EC}_{\mathrm{e}}=5.22 \mathrm{dS} \mathrm{m} \mathrm{m}^{-1}$. Excess and limited water applications in the irrigation regime experiment also reduced WUE significantly.

As seen in Figure 4a, daily evapotranspiration decreased as soil salinity increased. Daily ET can be divided into three distinct stages for all treatments in both experiments except for $\mathrm{S}_{6}$. In $\mathrm{S}_{6}$ treatment, daily ET was nearly constant from the beginning of the experiment to the $240^{\text {th }}$ day of the year and then it decreased. Water consumption route of the pepper was changed by higher salinity.

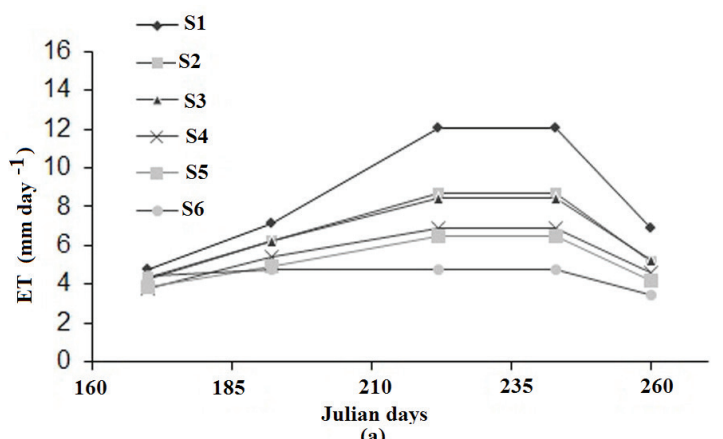

(a)

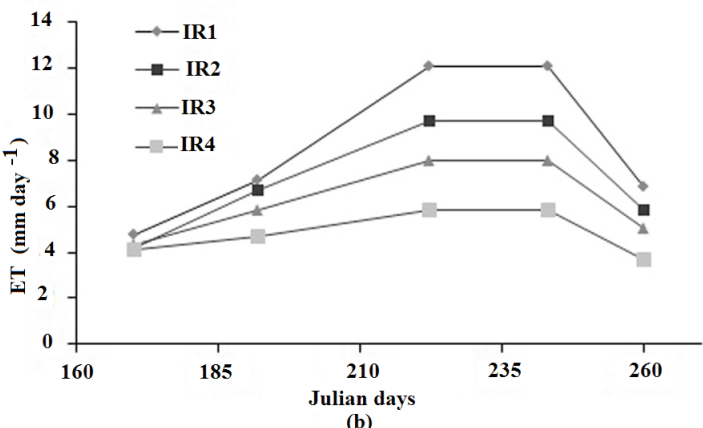

(b)

Figure 4- Effect of salinity (a) and water stress (b) on daily evapotranspiration of green long pepper

Şekil 4- Tuzluluk (a) ve su stresinin (b) sivri biberin günlük bitki su tüketimi üzerine etkisi

The relation between relative evapotranspiration and relative yield decreases for water stress with yield response factor $\left(\mathrm{K}_{\mathrm{y}}\right)$ has been used to evaluate plant tolerance to water stress (Doorenbos \&
Kassam 1986). Some scientists have also used this method for salinity assessments (Steawart et al 1977; Shalhevet 1994; Katerji et al 1998; Ünlukara et al 2008; Kurunç et al 2011). In our study, the relation between yield and evapotranspiration of pepper caused both by salinity and by limited water application were shown in Figure 5. As seen in Figure 5, the slopes of straight line $\left(\mathrm{K}_{\mathrm{y}}\right)$ were 1.56 for salinity and 1.66 for water stress. Although different forces act on plant water uptake under saline and water stress conditions, nearly the same $\mathrm{K}_{\mathrm{y}}$ coefficient obtained for both stresses. According to $\mathrm{K}_{\mathrm{y}}$ value, pepper was very sensitive to water deficit caused by salinity or water stress. Dimitrov \& Ovtcharrova (1995) reported that the pepper plant has a shallow root system and extracts $70-80 \%$ of its water from the top $0.3 \mathrm{~m}$ soil layer. Shallow root system and high stomatal density of pepper explains why pepper is regarded as relatively vulnerable to water stress (Ben-Gal et al 2008).

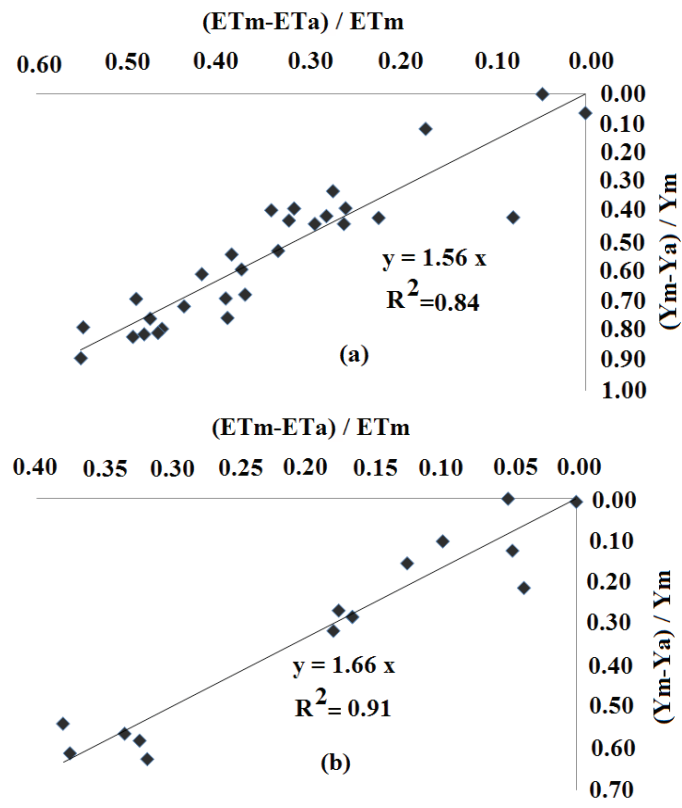

Figure 5-The relation between relative yield decrease and relative evapotranspiration decrease due to salinity (a) and irrigation regime (b) for green long pepper

Şekil 5- Tuzluluk (a) ve sulama rejimi (b) nedeni ile sivri biberde nispi verim kaybı ve nispi bitki su tüketimi kaybı arasındaki ilişki 


\section{Conclusions}

Long green pepper (Capsicum annuum var. Demre) is a sensitive plant to salinity and water stress caused by water deficit or soil salinity. Salinity and water deficit caused more yield decrease than plant growth. Harmful effect of water stress and salinity on yield improved total soluble solids in fruit. Relative fruit yield decreased linearly for unit increase of soil salinity but relative evapotranspiration decreased exponentially. Depressing effect of salinity on plant water consumption must be considered to avoid excess water application to plant and to keep environment. Yield response factor for water deficit is nearly similar to yield response factor for salinity. Considering plant water consumption as a second parameter in the salinity models may reflect effects of climatic conditions on plant salt tolerance. Especially relative evapotranspiration should be considered in the salinity models.

\section{References}

Aktas H, Abak K \& Cakmak I (2006). Genotypic variation in response of pepper to salinity. Scientia Horticulturae 110: 260-266

Allen R G, L S Pereira, D Raes \& M Smith (1998). Crop evapotranspiration. Guidelines for computing crop water requirements. FAO Irrigation and Drainage Paper 56, Rome

Azuma R, Ito N, Nakayama N, Suwa R, Nguyen N T, J Larrigana-Mayoral A, Esaka M, Fujiyama H \& Saneoka H (2010). Fruits are more sensitive to salinity than leaves and stems in pepper plants (Capsicum annuum L.). Scientia Horticulturae 125: 171-178

Ben-Gal A, Ityel E, Dudley L, Cohen S, Yermiyahu U, Presnov E, Zigmond L \& Shani U (2008). Effect of irrigation water salinity on transpiration and on leaching requirements: A case study for bell peppers. Agricultural Water Management 95: 587-597

Cemek B, Ünlükara A, Karaman S \& Gökalp Z (2011). Effects of evapotranspiration and soil salinity on some growth parameters and yield of lettuce (Lactuca sativa var. crispa). Zemdirbyste-Agriculture 98(2): 139-148

Chartzoulakis K \& Klapaki G (2000). Response of two greenhouse pepper hybrids to $\mathrm{NaCl}$ salinity during different growth stages. Scientia Horticulturae 86: 247-260
Dimitrov Z \& Ovtcharrova A (1995). The productivity of peppers and tomatoes in case of insufficient water supply. In: Proceedings of ICID Special Technical Session on the Role of Advanced Technologies in Irrigation and Drainage Systems 1: Ft9.1-ft9.5

Doorenbos J \& Kassam A H (1986). Yield response to water. FAO Irrigation and Drainage Paper 33, Rome

Dorji K, Behboudian M H \& Zegbe-Dominguez J A (2005). Water relations, growth, yield, and fruit quality of hot pepper under deficit irrigation and partial root zone drying. Scientia Horticulturae 104: 137-149

Düzdemir O, Ünlükara A \& Kurunç A (2009). Response of cowpea (Vigna unguiculata) to salinity and irrigation regimes. RSZN New Zealand Journal of Crop and Horticultural Science 37: 271-280

Ezzo M I, Glala A A, Habib H A M \& Helaly A A (2010). Response of Sweet Pepper Grown in Sandy and Clay Soil Lysimeters to Water Regimes. AmericanEurasian Journal of Agricultural \& Environment Science 8 (1): 18-26

FAO (2014a). FAOSTAD. Retrieved in January, 13, 2014 from http://faostat.fao.org/site/567/default. aspx\#ancor

FAO (2014b). FAOSTAD. Retrieved in January, 13, 2014 from http://faostat.fao.org/site/339/default.aspx

Francois L E \& Maas E V (1999). Crop Response and Management of Salt-Affected Soils. In: Pessarakli M. (ed): Handbook of Plant and Crop Stress, CRC Taylor \& Francis Group, New York, pp. 169-201

Genhua N, Rodriguez D S, Call E, Bosland P W, Ulery A \& Acosta E (2010). Responses of eight chile peppers to saline water irrigation. Scientia Horticulturae 126: 215-222

Hoffman G J \& Letey J (1990). Salinity Management. In: Management of Farm Irrigation Systems. ASAE Monograph Number 9, 2950 Niles Road St. Joseph, MI 49085-9659, USA

Katerji N, Van Hoorn J W, Hamdy A, Mastrorilli M \& Karam F (1998). Salinity and drought, a comparison of their effects on the relationship between yield and evapotranspiration. Agricultural Water Management 36: $45-54$

Kurunc A, Unlukara A \& Cemek B (2011). Salinity and drought affect yield response of bell pepper similarly. Acta Agriculturae Scandinavica, Section B - Plant Soil Science 61: 514-522 
Letey J \& Dinar A (1986). Simulated crop-water production functions for several crops when irrigated with saline waters. Hilgardia 54: 1-32

Maas E V \& Hoffman G J (1977). Crop salt toleranceCurrent assessment. ASCE Journal of Irrigation and Drainage Division 103: 115-134

Ozturk A, Unlukara A, Ipek A \& Gurbuz B (2004). Effects of Salt Stress and Water Deficit on Plant Growth and Essential Oil Content of Lemon Balm (Melissa officinalis L.). Pakistan Journal of Botany 36(4): 787792

Pessarakli M \& Szabolcs I (1999). Soil Salinity and Sodicity as Particular Plant/Crop Stress Factors. In: Pessarakli, M (ed): Handbook of Plant and Crop Stress, CRC Taylor \& Francis Group, New York, pp. $1-17$

Rhoades J D, Kandiah A \& Mashali A M (1992). The use of saline waters for crop production. FAO Irrigation and Drainage Paper 48, Rome

Richards L A (1969). Diagnosis and Improvement of Saline and Alkali Soils. United States Salinity Laboratory Staff, Agriculture Handbook No.60, United State Department of Agriculture, pp. 160
Shalhevet J (1994). Using water of marginal quality for crop production: major issues. Agricultural Water Management 25: 233-269

Steawart J I \& Hagan R M (1973). Functions to predict effects of crop water deficits. ASCE Journal of Irrigation Drainage Division 99: 421-439

Steaward J L, Danielson R E, Hanks R J, Jackson E B, Hagon R M, Pruit W O, Franklin W T \& Riley J P (1977). Optimizing crop production through control of water and salinity levels in the soil. Utah Water Research Lab. PR. 151-1, Logan, Utah

Yurtseven E, Kesmez G D \& Ünlükara A (2005). The effects of water salinity and potassium levels on yield, fruit guality and water consumption of a native central anatolian tomato species (Lycopersicon esculentum). Agricultural Water Management 78: 128-135

Ünlükara A, Kurunç A, Kesmez G D \& Yurtseven E (2008). Growth and evapotranspiration of okra (Abelmoschus esculentus L.) as influenced by salinity of irrigation water. Journal of Irrigation and Drainage Engineering 134(2): 160-166

Ünlükara A, Kurunç A, Kesmez G D, Yurtseven E \& Suarez D L (2010). Effects of Salinity on Eggplant (Solanum Melongena L.) Growth and Evapotranspiration. Irrigation and Drainage 59: 203-214 